\title{
Exploring the direct relationship between GDP per-capita and financial inclusion
}

\author{
Saurabh Sonkar ${ }^{1 *}$, Ashoke Kr Sarkar ${ }^{2}$ \\ Central University of Jharkhand, Ranchi, India ${ }^{1,2}$ \\ sonkarsaurabh23@gmail.com
}

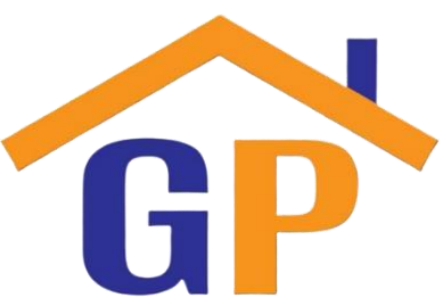

Article History

Received on 11 December 2020

$1^{\text {st }}$ Revision on 23 December 2020

$2^{\text {nd }}$ Revision on 14 January 2021

Accepted on 8 February 2021

\begin{abstract}
Purpose: This paper predicted the direct relationship between the four indicators of "Financial Inclusion" and "GDP per-capita" of the country. Previous studies presented in this scenario are qualitative in nature.
\end{abstract}

Research methodology: In this paper, "step-wise multiple linear regression" is used to establish the cause-and-effect relationship between the four indicators of "financial inclusion"; "Deposit accounts per 1000 population"; "Number of credit accounts per 1,000 people"; "Bank branches per 100,000 of adult population", and "ATMs per 100,000 of adult population" and "GDP per capita".

Results: Regression model showed only "Credit accounts per 1,000 people" have a significant relationship with the "GDP per capita". In this article, secondary data were obtained from the RBI website and the reports of international financial institutes.

Limitations: Data on "ATMs" and "Bank branches per 100,000 of the adult population" is not present before 2004, decreasing the depth of analysis.

Contribution: There is a cause-and-effect relationship between the country's "GDP per capita" and the "F.I." "Credit accounts per 1,000 people" only have a significant relationship with GDP per capita, so the change in the number of credit account will show a change in GDP per capita for Indian economy.

Keywords: Financial inclusion (F.I), GDP (Gross Domestic Product) per capita, Deposit accounts, Credit accounts, ATMs (Automated Teller Machines), Bank branches

How to cite: Sonkar, S., \& Sarkar, A.K. (2020). Exploring the direct relationship between GDP per-capita and financial inclusion. Annals of Management and Organization Research, 1(3), 187-202.

\section{Introduction}

The paper aims to create a cause-and-effect relationship between the "Financial inclusion" and the "GDP per capita, so it is necessary to consider the "F.I" and its indicators, and GDP per capita, one by one. "Financial inclusion" is essential for improving the quality of life of people of all nations, including poor farmers, rural non-farm businesses and other disadvantaged groups (Jayanthi \& Rau, 2017). In India, "financial inclusion" marks can be traced back to 1969 when 14 banks were nationalized under (Sathye, 2003) "Banking Companies (Acquisition and Transfer of Undertakings) Ordinance, 1969" and it came in to force from midnight on 19 July 1969, and that bank's accounted for 85 percent of the bank deposits of that time. In 1980, six more banks were nationalized in which the Indian government managed 91 percent of India's banking sector. The nationalization of banks in "1969 and 1980" has contributed to expanding commercial banks' regional and operating reach, Regional Rural Banks (RRB's) and cooperative credit institutions. Despite the tremendous expansion of banking services in rural and remote areas major portion of the population including farmers, people from weaker section of society and the low-income category remained disconnected from opportunities and facilities offered by the financial sector (Iqbal \& Sami, 2017). So there is a need to expand financial inclusion in the entire society and PMJDY is a good step towards it. "Financial Inclusion" plays a crucial role in this 
socioeconomic development of its citizens. So different scholars and academicians defined it in different ways, which is given in Table 1.

Table 1. Financial inclusion definition

\begin{tabular}{|c|c|c|c|}
\hline $\begin{array}{l}\text { Sr. } \\
\text { No }\end{array}$ & Year & Author & Definition \\
\hline 1 & 1995 & $\begin{array}{l}\text { (Leyshon \& Thrift, } \\
\underline{1995)}\end{array}$ & $\begin{array}{l}\text { "Financial exclusion as referring to those processes that } \\
\text { serve to prevent certain social groups and individuals } \\
\text { from gaining access to the formal financial system." }\end{array}$ \\
\hline 2 & 2005 & $\begin{array}{ll}\text { (Santiago } & \text { Carbo, } \\
\underline{2005)} & \end{array}$ & $\begin{array}{l}\text { Financial exclusion has been widely described as the } \\
\text { incapability of some groups of society to access financial } \\
\text { services and products. }\end{array}$ \\
\hline 3 & 2006 & (Conroy, 2006), & $\begin{array}{l}\text { "Financial exclusion is a process that prevents poor and } \\
\text { disadvantaged social groups from gaining access to the } \\
\text { formal financial systems of their countries." }\end{array}$ \\
\hline 4 & 2006 & (Mohan, 2006) & $\begin{array}{l}\text { "Financial exclusion signifies the lack of access by } \\
\text { certain segments of the society to appropriate, low-cost, } \\
\text { fair and safe financial products and services from } \\
\text { mainstream providers". }\end{array}$ \\
\hline 5 & 2011 & $\underline{\text { (Mandira }}$ Sarma, & $\begin{array}{l}\text { "Financial inclusion refers to a process that ensures the } \\
\text { ease of access, availability and usage of the formal } \\
\text { financial system for all members of an economy." }\end{array}$ \\
\hline 6 & 2011 & $\begin{array}{l}\text { (C. Kumar \& Mishra, } \\
\underline{\text { 2011). }}\end{array}$ & $\begin{array}{l}\text { The ongoing method of providing all sections of society } \\
\text { with links to financial services and products at a } \\
\text { reasonable price is called financial inclusion. }\end{array}$ \\
\hline 7 & 2014 & (Kapoor, 2014) & $\begin{array}{l}\text { "Financial inclusion is an equalizer that enables all } \\
\text { citizens to contribute to economic growth and to gain } \\
\text { from it." }\end{array}$ \\
\hline 8 & 2015 & $\begin{array}{l}\text { (Sahay, Cihak, } \\
\text { N'Diaye, Barajas, \& } \\
\text { Mitra, 2015) }\end{array}$ & $\begin{array}{l}\text { "It is the access to and use of formal financial services by } \\
\text { households and firms." }\end{array}$ \\
\hline 9 & 2016 & (J. H. Kim, 2016) & $\begin{array}{l}\text { "Financial inclusion generally refers to a state in which } \\
\text { all working-age adults have effective access to credit, } \\
\text { savings, payments, and insurance from formal service } \\
\text { providers." }\end{array}$ \\
\hline
\end{tabular}

Apart from scholars and academicians, government organizations and committees also described financial inclusion in the following manner:

(RBI, 2008) defines "Financial inclusion" as a mechanism to ensure the availability of financial resources and timely and sufficient credit where disadvantaged populations, such as poor sections and low-income groups, are required at an affordable rate (Bhaskar, 2013). According to Chakraborty (2011), "financial inclusion" is the mechanism by which, at an acceptable rate, conventional institutional actors are equal and open in their access to appropriate financial products and services required by all sectors of society, including lower classes and lower-income groups (Central, 2011). "Financial inclusion is the process of ensuring access to appropriate financial products and services needed by all society members in general and vulnerable groups in particular, at an affordable cost fairly and transparently by mainstream institutional players" (Chakrabarty, 2012).

"Financial inclusion" provides financial services to all the segments of society with particular importance to the economically backward section of society at an affordable cost. The "Financial Inclusion" strategy aims to increase the number of account holders in banks and other financial institutes. 
A next important question is what are the "financial inclusion Indicators" in case of India. (Reyes, 2010) in her report divided the "financial inclusion indicators" into two groups qualitative and quantitative indicators. In quantitative she considered "number of bank branches per 10000 population", "number of ATMs per 10000 population", "number of agents per 10000 population" in Access domain similarly in uses she included "Number of depositors per 1000 populations", "Number of borrowers per 1000 populations", "Average size of total deposits per depositor" to "GDP per capita", "Average size of total loans per borrower" to "GDP per capita" and "Population not covered by financial services" and in third domain availability she considered "borrower present in the region, distribution of agents" and "socioeconomic needs along with total loan provided in the region." Similarly (Lenka \& Sharma, 2017) considered " bank accounts per 1,000 people; the number of bank branches and ATMs per 100,000 adult population and amount of bank deposits" as four significant financial inclusion indicators that can be used as a measure of financial inclusion. Apart from these indicators many other indicators of "financial inclusion" have been formulated by the different organization across the globe which are given in table: 2 as follows

Table 2. Indicators of financial Inclusion

\begin{tabular}{|c|c|c|c|}
\hline Sr. No & Year & Organizations/Institutions/Authors & Indicators of financial Inclusion \\
\hline 1 & 2000 & "Asian Development Bank (ADB)" & $\begin{array}{l}\text { "Deposits, loans, payment services, } \\
\text { money transfer and insurance." }\end{array}$ \\
\hline 2 & 2001 & "Stephen P. Sinclair" & $\begin{array}{l}\text { "Basic banking services for money } \\
\text { transmission, credit, insurance, debt } \\
\text { and debt assistance, long-term } \\
\text { savings and financial literacy." }\end{array}$ \\
\hline 3 & 2004 & "Chant Link and Associates, Australia" & $\begin{array}{l}\text { "Deposit accounts, direct } \\
\text { investments, home loans, credit } \\
\text { cards, personal loans, building } \\
\text { insurance and home insurance". }\end{array}$ \\
\hline 4 & 2004 & $\begin{array}{l}\text { "Treasury Committee, House of } \\
\text { Commons, UK" }\end{array}$ & $\begin{array}{l}\text { "Affordable credit and savings for all } \\
\text { and access to financial advice". }\end{array}$ \\
\hline 5 & 2005 & "Scottish Government" & $\begin{array}{l}\text { "Access to products and services, } \\
\text { and/or capacity, skills, knowledge } \\
\text { and understanding". }\end{array}$ \\
\hline 6 & 2006 & "United Nations" & $\begin{array}{l}\text { "Access to credit, insurance, savings, } \\
\text { payment services." }\end{array}$ \\
\hline 7 & 2008 & $\begin{array}{l}\text { "Report of the Committee on Financial } \\
\text { Inclusion in India (Rangarajan, 2008)" }\end{array}$ & $\begin{array}{l}\text { "Access to financial services and } \\
\text { timely and adequate credit". }\end{array}$ \\
\hline 8 & 2008 & "World Bank" & $\begin{array}{l}\text { "Access to financial services such as } \\
\text { deposit, credit, payments and } \\
\text { insurance." }\end{array}$ \\
\hline 9 & 2012 & $\begin{array}{l}\text { "Financial Inclusion }- \text { Issues } \\
\text { Measurement and Analysis* } \\
\text { Chakrabarty" }\end{array}$ & $\begin{array}{l}\text { "Credit, Insurance, Payments, } \\
\text { Savings." }\end{array}$ \\
\hline 10 & 2012 & "IFM" & $\begin{array}{l}\text { "ATMs per } 1,000 \mathrm{~km} \text {, ATMs per } \\
100,000 \text { adults, Commercial bank } \\
\text { branches per } 1,000 \mathrm{~km} \text {, Commercial } \\
\text { bank branches per } 100,000 \text { adults, } \\
\text { Deposit accounts with commercial } \\
\text { banks per } 1,000 \text { adults, Household } \\
\text { deposit accounts with commercial } \\
\text { banks per } 1,000 \text { adults, Household } \\
\text { loan accounts with commercial } \\
\text { banks per } 1,000 \text { adults, Loan } \\
\text { accounts with commercial banks per }\end{array}$ \\
\hline
\end{tabular}

2020 | Annals of Management and Organization Research / Vol 1 No 3, 187-202 


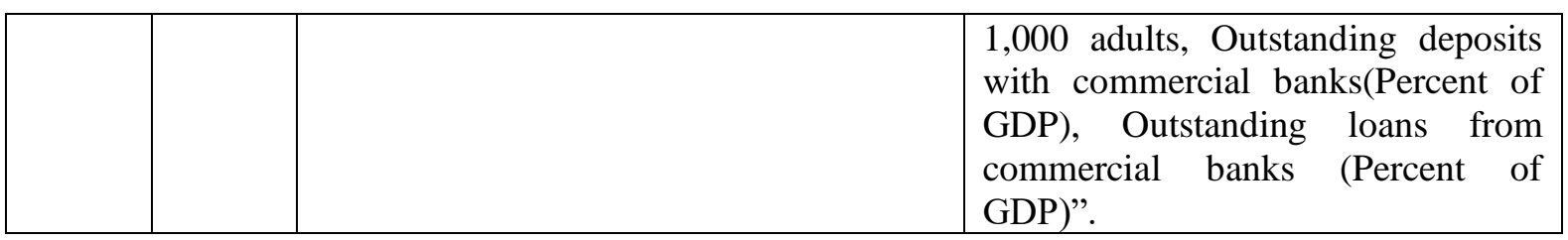

Source: (Kablana \& Chhikara, 2013), \&IMF’s Financial Inclusion Survey July 2012.

The "Financial Inclusion" strategy aims to increase the number of account holders in banks and other

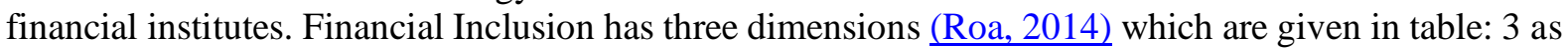
follow:

Table 3. Financial inclusion dimensions

\begin{tabular}{|l|l|}
\hline ACCESS & $\begin{array}{l}\text { Availability of formally regulated financial services and products at affordable cost. } \\
\text { It has been measured by the "number of bank A/C per 1,000". }\end{array}$ \\
\hline USAGE & $\begin{array}{l}\text { True use of financial services and products: Regularity, Frequency of use and } \\
\text { period of use. It applies to the combined volume of GDP deposits and loans. }\end{array}$ \\
\hline QUALITY & $\begin{array}{l}\text { Products are according to customers' needs and should be developed according to a } \\
\text { different society segment. }\end{array}$ \\
\hline
\end{tabular}

Measuring "F.I" is essential because it helps to understand the result of various measures considered by stakeholders and in order to decide which plan to follow (Ambarkhane, Singh, \& Venkataramani, 2016). The bank framework plays a vital role in bringing the financially excluded under the financial framework (Srinivasan, 2007). The study focuses on building the relationship between various "F.I" indicators and India's "GDP per capita". These financial indicators are chosen based on the IMF financial inclusion survey glossary (Fund, n.d.). The relationship between four indicators of "F.I" and "GDP per-capita" of India is established in this study by using step-wise multiple linear regressions. "GDP per capita" is dependent variable and four "F.I" indicators are independent variables. The "GDP per capita" means gross GDP divided by the country's estimated adult population as of first July of the same year (Rahman, 2013). This study gains importance as this is the era of inclusive development for developing countries and financial inclusion is vital (A. Sharma \& Sumita, 2013). The study focuses on the relationship between four major "F.I" indicators and "GDP per-capita."

\section{Literature review and hypotheses development}

"F.I" is defined as a system providing easy access to financial services and products to its citizens (Iqbal \& Sami, 2017). But looking at the significant work on financial inclusion, we find that "F.I" is defined primarily as the ongoing process $\underline{\text { Bech \& Kunt, 2012) }}$ of bringing the vulnerable under the financial network.

The Indian banking industry has blossomed both technically and size wise and provided healthy and affordable banking services to its citizens in the last few decades (N. Kumar, 2013). Banks' role gains more importance in the development of the Indian economy as banks help in the mobilization and circulation of finance, which is the key requirement for developing any economy (Joseph \& Varghese, 2014). The supply-side of banking data is useful in measuring financial inclusion (Chakravarty \& Pal, 2013). (Sarma, 2008) in her paper developed a Financial index using the four indicators of "financial inclusion," including "number of bank account per hundred of populations", "number of bank branches per thousand of populations," and "the ratio of saving and credit account to the GDP of the country". Researchers and academicians have tried to find a relation between "financial inclusion" and economic development.GDP isevery country's economic growth indicators. GDP influences the financial inclusion significantly (Evans \& Alenoghena, 2017). The research conducted in Kenya shows that the "F.I" has direct relationship with economic development (Julie, 2013). For poor people, access to 
finance is key for removing poverty to achieve inclusive growth and substantial economic development (Swamy, 2010). Financial inclusion helps eradicate poverty in turn, helps in inclusive development and achieving the millennium development goal (Chibba, 2009). Financial inclusion has four major indicators " bank accounts per 1,000 people; several bank branches and ATMs per 100,000 adult populations and amount of bank deposits" (Lenka \& Sharma, 2017)(Sarma, 2008b).

"F.I" and economic development are related together in the long term (Sethi \& Sethy, 2019). Research conducted on 55 OIC "\{Organization of Islamic Cooperation\}" countries by using the "Dynamic panel, VAR, IRFs and the Panel granger causality test" suggested that "F.I" has a favorable economic development effect (D. W. Kim, Yu, \& Hassan, 2018). A similar type of research is also done for the set of 31 countries fixing the bond between countries' economic growth and "F.I" (Dinabandhu Sethi, 2018). Banking side data may be used to calculate the financial inclusion (Chakravarty \& Pal, 2013). There is a positive relationship between country's economic growth and different financial inclusion indicators, including banking penetration, availability, and usage of banking in terms of deposits to its citizens(D. Sharma, 2016). Financial inclusion is not always a result of economic development in any country, but it may be the driver of economic growth, as Nigeria's case (Babajide, Adegboye, \& Omankhanlen, 2015). The number of active ATMs, bank branches and government expenditure are the strongest indicator of "F.I" for the poverty reduction in developing country (Williams, Adegoke, \& Dare, 2017)

There is a relationship between the domestic credit by the banking sector and GDP per capita in balanced payment framework in Latin American countries between 1960 to 2010 (Gozgor \& Gozgor, 2013). Similar kind of relationship can exist between number of credit and debit accounts present in India, which we attempt to predict in the paper. Financial inclusion is the driver of economic growth (Dinabandhu Sethi, 2018) proved by establishing the long term relationship between financial inclusion and economic growth by running a panel causality test that shows bi-panel causality.

Financial inclusion plays a significant role in reducing the income inequality in developing Asian countries (Park \& Mercado, 2015) for this they used four indicators of financial inclusion including "automated teller machines (ATMs) per 100,000 adults", "commercial bank branches per 100,000 adults", "borrowers from commercial banks per 1,000 adults", "depositors with commercial banks per 1,000 adults", and "domestic credit to GDP ratio". There exist a unidirectional relationship between financial inclusion and economic growth (Lenka \& Sharma, 2017) they focused on the indicators of financial inclusion like "deposit and credit accounts from scheduled commercial banks per 1000 adults", "number of bank branches per 1000 adults" and "number of bank employees as per the ratio of bank branches".

In this study, a relationship is being established between "F.I" and "GDP per-capita" using banking data. It has been observed that many studies are not present representing the direct relationship between the indicators of "financial inclusion" and "GDP per capita" for Indian economy.

Research Gap: Financial inclusion is an ongoing phenomenon that started with the nationalization of banks in India in 1969. Many steps are being taken by the Indian government, including the introduction of PMJD \{Pradhan Mantri Jandhan Yojana\}, and the introduction of Payment banks in 2017. Financial inclusion is a vital step towards the economic growth of India. Some studies are conducted through scholars and academicians by individual states and banks. However, very few studies are present in framing cause and effect relationship between four indicators of "financial inclusion" and "GDP per capita" of our country. Hence, in the study we tried to predict the cause and effect relationship between the two.

\section{Objective}

1 To demonstrate the relationship between the numbers of accounts' credit and deposit with "per capita GDP" of the country.

2 To examine the relationship between the "Bank branches and ATMs per 100,000 of adult population" with "GDP per capita." 
Hypothesis Framed: In order to check this relationship between the "GDP per capita" and "financial inclusion" in Indian scenario, a series of Hypothesis are framed and tested between major four factors of "financial inclusion" and "GDP per capita" which are as follows:

H01: The relationship between "F.I" and "GDP per capita" is not significant.

$>$ H01a: -Insignificant relationship is present between the number of "Deposit account per thousand people" and "Per capita GDP."

$>$ H01b: -Insignificant relationship is present between the number of "Credit account per thousand population" and "Per capita GDP."

$>$ H01c: -Significant relationship is not present between the numbers of "ATMs per 100,000 of adult's populations" and "GDP per capita."

$>$ H01d: Significantrelationship is not present between the number of" Bank branches per 100,000of adults" and "GDP per capita."

\section{Research methodology}

In this paper, exploratory research methodology is used. Secondary data is collected from RBI reports, Inclusive Finance India report, IBEF report, Global Findex database, and World bank reports. In this paper step-wise multiple linear regression is applied to evaluate the cause and effect relationship between "GDP per capita" and four indicators of "F.I" including "Number of ATMs per 100,000 of adults population ; Bank branches per 100,000 of adults population" (D. Sharma, 2016) and "number of deposit and credit accounts per 1000 populations" respectively (Sarma, 2008b) for this purpose regression model is proposed in the paper. SPSS 21 is used in research for examination.

\section{Results and discussions}

\section{Penetration trend in bank branches, ATMs and Accounts}

Over the last two decades, the number of account holders has increased in India due to financial inclusion and the number of branches and "ATMs" has increased at a significant rate. Table: 4 is showing data from 2005 to 2017.

Table 4. (Data is taken from RBI and World bank)

\begin{tabular}{|l|c|c|c|c|c|}
\hline Years & $\begin{array}{c}\text { "Numbers of bank } \\
\text { branches per } \\
\text { 100000 adult } \\
\text { population" }\end{array}$ & $\begin{array}{c}\text { "Number of } \\
\text { ATMs per } \\
\text { 100000 adult } \\
\text { population" }\end{array}$ & $\begin{array}{c}\text { "Number of } \\
\text { deposit } \\
\text { accounts per } \\
\text { 1000 } \\
\text { population" }\end{array}$ & $\begin{array}{c}\text { "Number of } \\
\text { credit } \\
\text { accounts per } \\
\text { 1000 } \\
\text { population" }\end{array}$ & $\begin{array}{c}\text { "GDP per- } \\
\text { capita" }\end{array}$ \\
\hline $\mathbf{2 0 0 5}$ & 8.8999 & 2.2871 & 406.7514 & 67.2275 & 714.8610 \\
\hline $\mathbf{2 0 0 6}$ & 8.8700 & 2.7329 & 416.2193 & 73.3050 & 806.7532 \\
\hline $\mathbf{2 0 0 7}$ & 8.9799 & 3.3700 & 438.8056 & 79.8184 & 1028.3347 \\
\hline $\mathbf{2 0 0 8}$ & 9.2862 & 4.2770 & 484.4437 & 89.1094 & 998.5223 \\
\hline $\mathbf{2 0 0 9}$ & 9.5751 & 5.2972 & 543.8849 & 90.3782 & 1101.9608 \\
\hline $\mathbf{2 0 1 0}$ & 10.0104 & 7.2489 & 595.3821 & 96.1272 & 1357.5637 \\
\hline $\mathbf{2 0 1 1}$ & 10.4863 & 8.8302 & 647.9543 & 96.5568 & 1458.1035 \\
\hline $\mathbf{2 0 1 2}$ & 11.1599 & 10.985 & 713.5505 & 103.3984 & 1443.8795 \\
\hline $\mathbf{2 0 1 3}$ & 11.8301 & 12.8435 & 815.9489 & 100.158 & 1449.6059 \\
\hline $\mathbf{2 0 1 4}$ & 12.8497 & 17.7720 & 946.8246 & 107.0928 & 1573.88149 \\
\hline $\mathbf{2 0 1 5}$ & 13.5571 & 19.6848 & 1099.0263 & 110.0940 & 1605.60543 \\
\hline $\mathbf{2 0 1 6}$ & 14.2644 & 21.2303 & 1242.8116 & 122.5917 & 1732.5642 \\
\hline $\mathbf{2 0 1 7}$ & 14.5680 & 22.07371 & 1364.5388 & 128.7736 & 1981.6510 \\
\hline
\end{tabular}

Table: 4 Depicts the increase in "Number of bank branches per 100,000 adult populations", "Number of ATMs per 100,000 adult populations"; "Number of deposit accounts per 1,000 populations" and "Number of credit accounts per 1000 populations" throughout 2005 and 2017 due to the various financial reforms carried out by the Indian government. 
"Table 5. Descriptive Statistics"

\begin{tabular}{|l|c|c|c|}
\hline & "Mean" & $\begin{array}{c}\text { "Std. } \\
\text { Deviation" }\end{array}$ & "N" \\
\hline "GDP Per Capita." & 1327.175902 & 373.2234237 & 13 \\
"Number of Bank Branches per 100,000 adult & 11.102846 & 2.1048155 & 13 \\
populations". & & & \\
"Number of ATMs per 100,000 adult populations". & 10.664047 & 7.3568518 & 13 \\
"Number of credit accounts per1, 000 populations". & 97.279308 & 17.8835183 & 13 \\
"Number of deposit accounts per 1,000 populations" & 747.395538 & 324.0453733 & 13 \\
\hline
\end{tabular}

\section{Figure 1}

Histogram

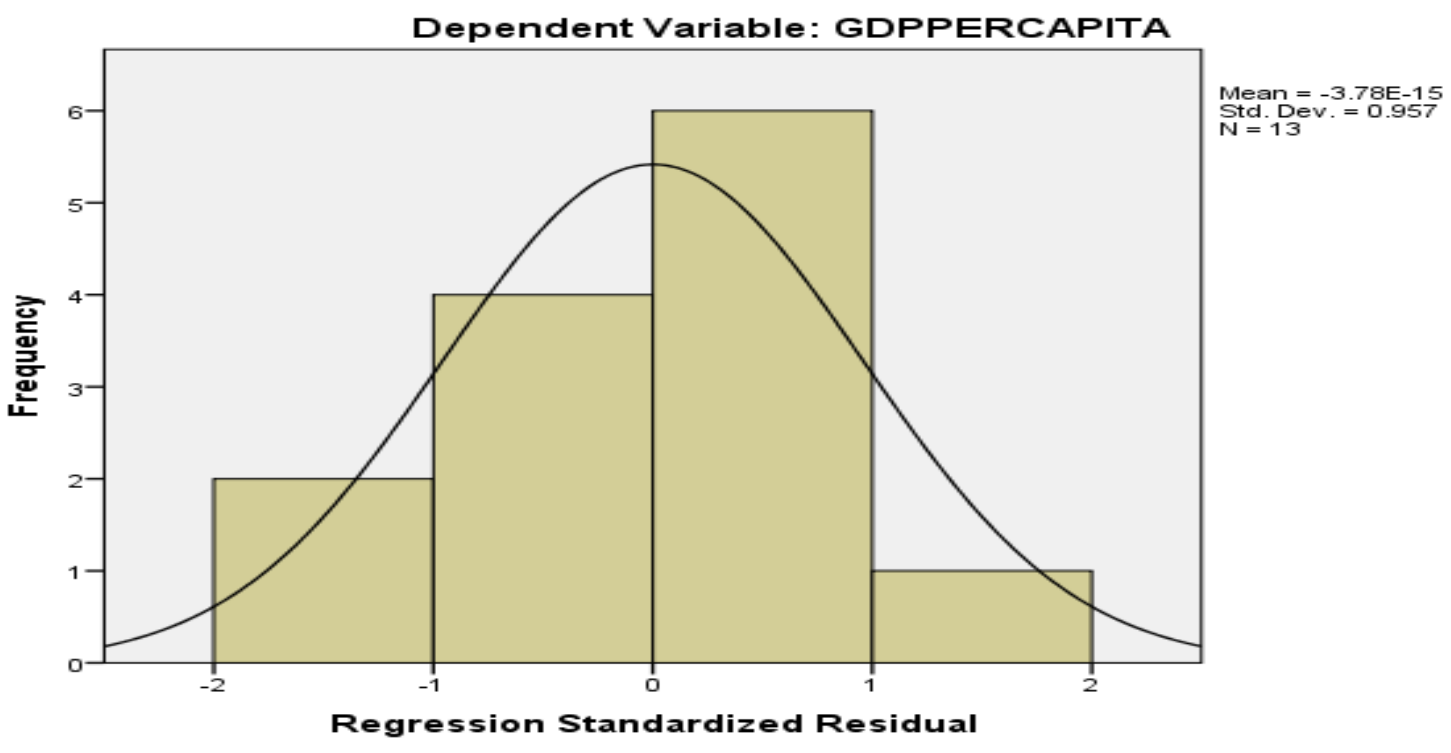

Figure 2

Normal P-P Plot of Regression Standardized Residual

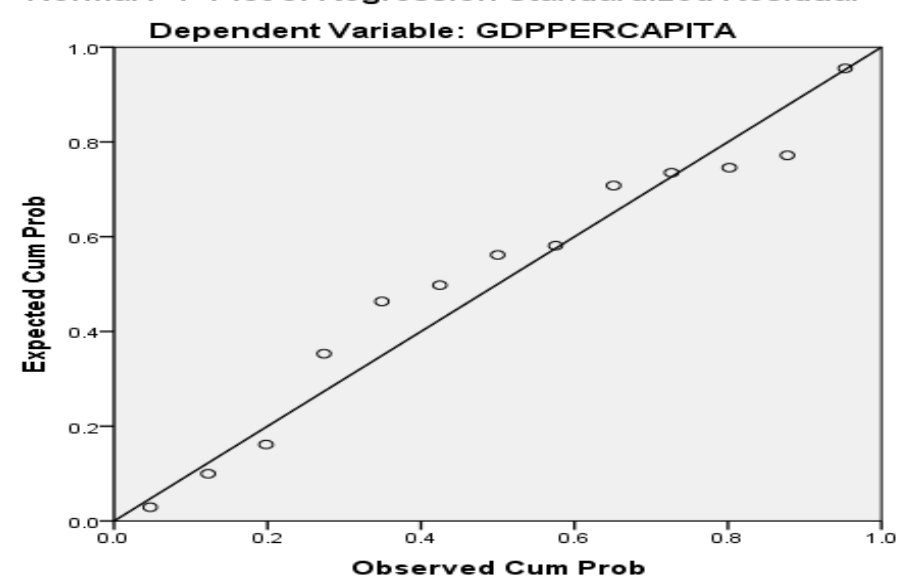

In figure 1 curve and histogram represent the linearity of data taken for regression analysis. While Figure 2 depicts the normality of data and it can be seen that the data used is normal up to some extent. 


\section{Figure 3}

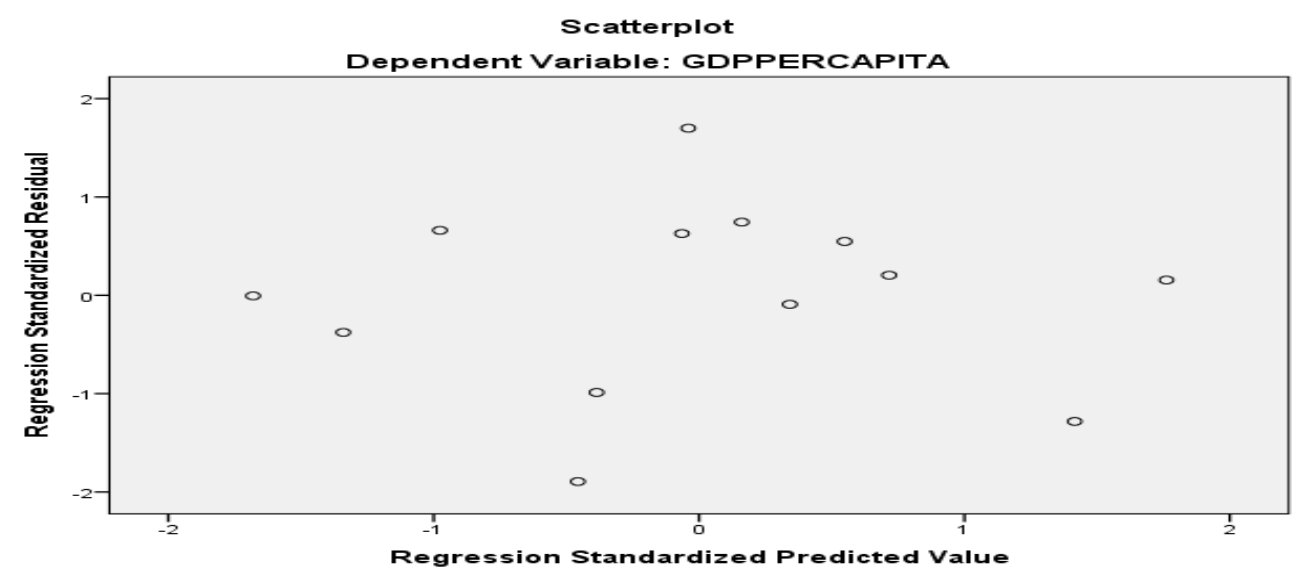

Figure 3 represents the homoscedasticity of the data taken in the analysis. Data is homogeneous as the points are somewhat scattered in the diagram and do not take any particular shape.

Figures $4 \& 5$ represent the number of "ATMs per 100,000 adult population" and "Bank branches per 100,000 adult population" and "GDP per capita," "Deposit acceunts per 1,000 people" and "Credit accounts per 1,000 people", respectively.

\section{Figure 4}

The following column graphs show the growth in the number of "ATMs and Bank branches per 100,000 adult populations" data is taken from $\underline{\mathrm{RBI}}$ reports and World Bank.

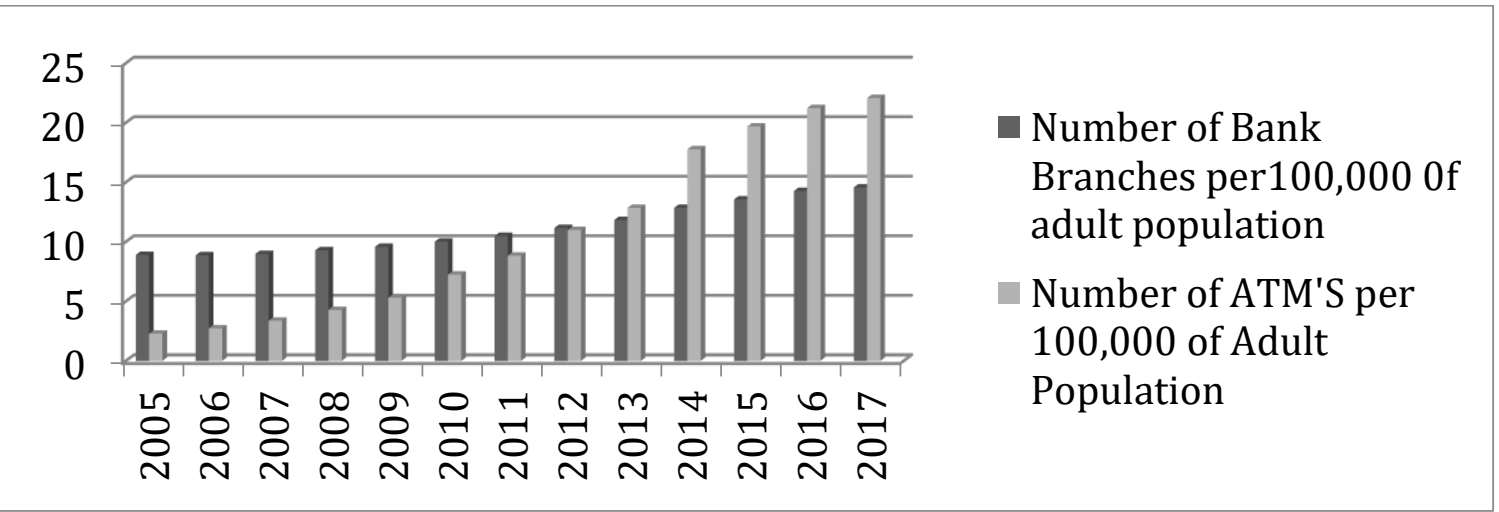




\section{Figure 5}

Growth in the number of "Deposit and credit accounts per 1,000 population" along with the change in" per capita GDP" over the years starting from 2005 to 2017 is shown below \{data is taken from

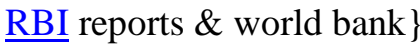

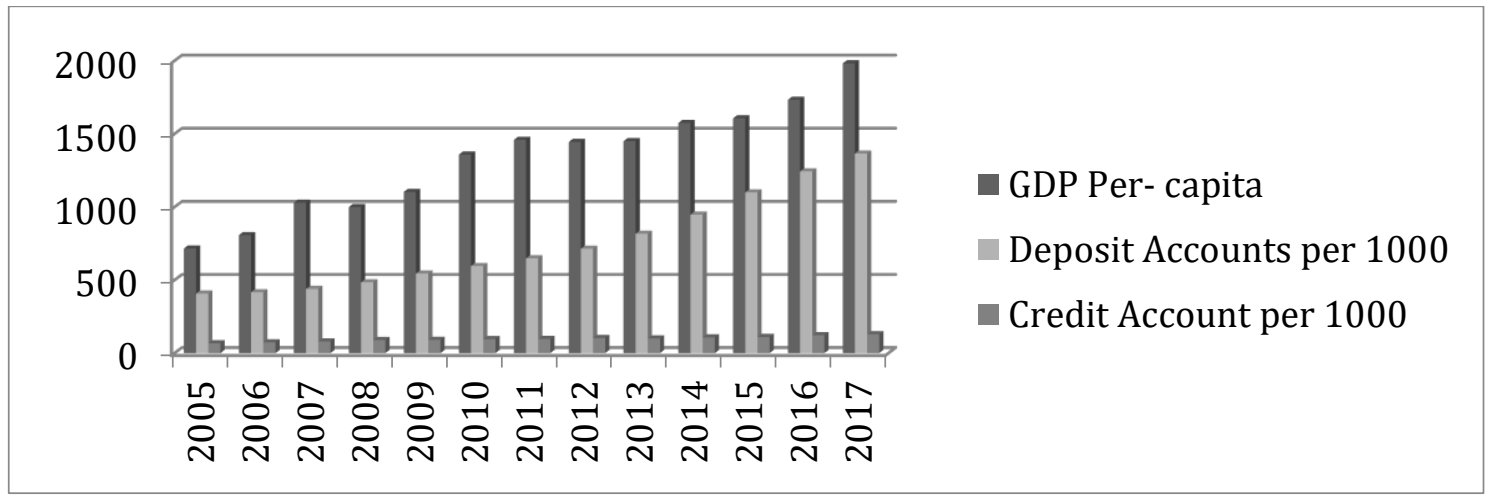

Note:

Number Of deposit accounts with commercial banks Total population of the country

\section{Number of loan accounts with commercial banks \\ Total population of the county $\mathrm{x} 1000$}

The financial inclusion index mainly depends on three parameters: -Accessibility, Availability and Utility.

Accessibility: Represents the "Bank accounts present per thousand of populations".

Availability: It is calculated by the number of "Bank branches and ATMs per 100,000 adult populations" (Sethi \& Sethy, 2019).

Utility: -Financial products are according to citizen needs.

Analysis and hypothesis testing: To test the relationships between four indicators of "F.I" and "per capita GDP" in the Indian scenario, a series of hypotheses are framed and tested which are as following:

Hypothesis Analysis: In hypotheses, an attempt is made to understand the relationship between the number of "Deposits accounts per thousand population" and "Credit accounts per thousand Population", "Bank branches and "ATMs per 100,000 adults populations" and "GDP per capita". For this, step-wise multiple linear regressions was carried out between the variables. In this study "GDP per capita" is taken as dependent variable and deposit accounts, credit accounts, bank branches, and ATMs as independent variables. The test is carried on the data from 2005 to 2017. The proposed model is given in "Table: 6."

Table 6. Model

\begin{tabular}{|l|l|l|l|l|l|}
\hline "Model" & "R Square" & $\begin{array}{l}\text { "Adjusted R } \\
\text { Square" }\end{array}$ & $\begin{array}{l}\text { "Std. Error of } \\
\text { the Estimate" }\end{array}$ & "R" & $\begin{array}{l}\text { "Durbin } \\
\text { Watson" }\end{array}$ \\
\hline 1 & .952 & .947 & 85.7040856 & $.976^{\mathrm{a}}$ & 1.879 \\
\hline
\end{tabular}


The given model in Table: 6 shows a 97.60\% correlation between dependent and independent variables. Its adjusted " $\boldsymbol{R}$ " square indicates that the credit accounts can estimate $94.70 \%$ of the GDP variance per capita per credit accounts 1,000 of the population. The value " $\boldsymbol{F}$ " is calculated by dividing the mean square regression value (1590751.595) by the mean square residual value (7345.190), yielding " $\boldsymbol{F}$ " = 216.571 as given in Table: 7. The "P" value or level of significance associated with " $\boldsymbol{F}$ " value is zero, which is less than the standard value of .05. So independent variable credit accounts for every one thousand people will estimate the GDP per capita. Details of the model are given in Table: 7.

Table 7. ANOVA ${ }^{a}$

\begin{tabular}{|c|c|c|c|c|c|}
\hline “Model" & $\begin{array}{c}\text { "Sum of } \\
\text { Squares" }\end{array}$ & "df" & $\begin{array}{c}\text { "Mean } \\
\text { Square" }\end{array}$ & "F" & "Sig" \\
\hline Regression & 1590751.59 & 1 & 1590751.59 & 216.571 & $.00^{\mathrm{b}}$ \\
\hline Residual & 80797.093 & 11 & 7345.190 & & \\
\hline Total & 1671548.688 & 12 & & & \\
\hline
\end{tabular}

a. "DependentVariable: GDP Per Capita"

b. "Predictors: (Constant), "Number of credit accounts per 1,000 of populations".

Table 8

\begin{tabular}{|c|c|c|c|c|c|c|c|c|c|c|c|c|c|}
\hline \multicolumn{14}{|c|}{ Coefficients $^{\mathrm{a}}$} \\
\hline \multirow{2}{*}{\multicolumn{2}{|c|}{ Model }} & \multicolumn{2}{|c|}{$\begin{array}{c}\text { "Unstandardized } \\
\text { Coefficients" }\end{array}$} & \multirow{2}{*}{$\begin{array}{c}\text { "Stand } \\
\text { ardized } \\
\text { Coeffic } \\
\text { ients" } \\
\text { "Beta" }\end{array}$} & \multirow[t]{2}{*}{$\mathrm{t}$} & \multirow[t]{2}{*}{ Sig. } & \multicolumn{2}{|c|}{$\begin{array}{c}\text { "95.0\% } \\
\text { Confidence } \\
\text { Interval for B" }\end{array}$} & \multicolumn{3}{|c|}{ "Correlations" } & \multicolumn{2}{|c|}{$\begin{array}{c}\text { "Collineari } \\
\text { ty } \\
\text { Statistics" }\end{array}$} \\
\hline & & "B" & $\begin{array}{l}\text { "Std. } \\
\text { Error" }\end{array}$ & & & & $\begin{array}{l}\text { "Lower } \\
\text { Bound" }\end{array}$ & $\begin{array}{l}\text { "Upper } \\
\text { Bound" }\end{array}$ & $\begin{array}{c}\text { "Zero } \\
- \\
\text { order" }\end{array}$ & $\begin{array}{l}\text { "Part } \\
\text { ial" }\end{array}$ & $\begin{array}{l}\text { "Par } \\
\text { t" }\end{array}$ & $\begin{array}{l}\text { "To } \\
\text { lera } \\
\text { nce }\end{array}$ & "VIF \\
\hline & (Constant) & -653.339 & $\begin{array}{r}136.66 \\
2\end{array}$ & & -4.781 & .001 & 954.131 & $352.547^{-}$ & & & & & \\
\hline 1 & $\begin{array}{l}\text { Number of } \\
\text { credit } \\
\text { accounts per } \\
1000 \\
\text { populations }\end{array}$ & 20.359 & 1.383 & .976 & $\begin{array}{r}14.71 \\
6\end{array}$ & .000 & 17.314 & 23.404 & .976 & .976 & .976 & 1.0 & 1.00 \\
\hline & Dependent $V_{c}$ & "GDF & $\mathrm{Can}$ & & & & & & & & & & \\
\hline
\end{tabular}

According to the details given in Table: 6 and Table: 8 there will be a change of .976 in "GDP per capita" for every unit change in credit accounts per 1,000 of the adult population. In this case " $t$ " value is 14.716 which is $>=2$ so the proposed hypothesis is false and the alternative hypothesis is true.

On testing Hypothesis H01a, H01c and H01d Table: 9 clearly demonstrate the step-wise multiple regression in three factors ("Bank branches per 100,000 of the adult population" ; "ATMs per 100,000 of adult population", "Deposit accounts per one thousand of the population") do not show a significant relationship with dependent variable "GDP per capita". "P" value or significance value for all three are $.670, .523, .892$ respectively which are comparatively larger than .05 as a result, and these three don't have a major impact on "GDP per capita". There will be a change of $.088, .132$ in "per capita GDP" for per unit change in "Bank branches per 100,000 adult population" and "ATMs per 100,000 adult population" respectively. This change of .030 will also be observed in "GDP per capita" with every unit change in "Deposit accounts per 1000 of the population". Results were found to support all of the proposed hypotheses. Table 9 
Table 9

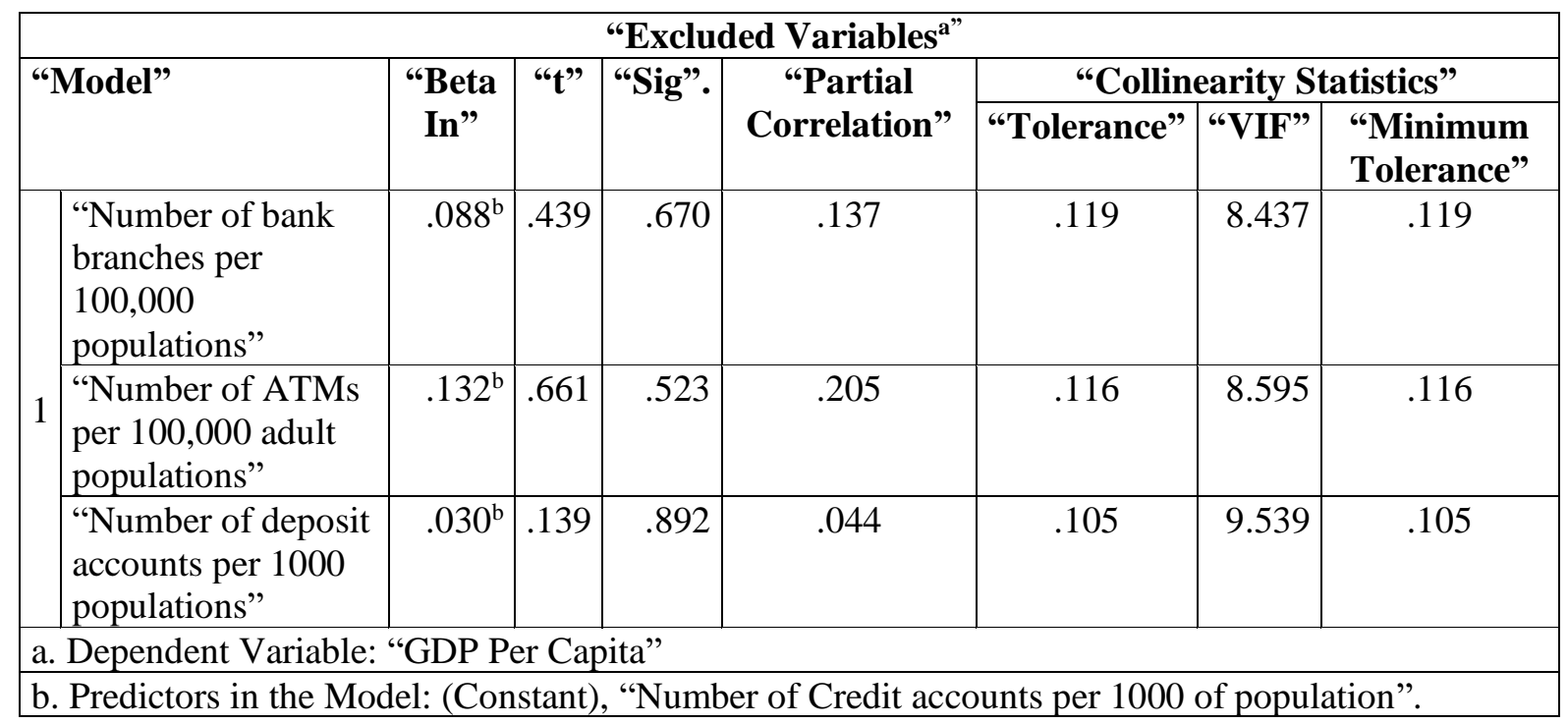

After using step-wise multiple linear regression, the t-values for Bank branches per lakh, ATMs per 100,000 of population and account debited per 1000 of a population are $.439, .661$, and .139 respectively which are less than 2, so the proposed hypothesis holds true. Apart from this, strong correlation is observed between GDP per capita and four indicators of financial inclusion. VIF value in case of credit accounts per 1000 population is 1.0, which is acceptable as a thumb rule says VIF value around 1 is good and anything less than 10 is acceptable. So the model is free from the problem of multicollinearity.

A VIF value equal to 1 for credit accounts per thousand of the population represents the complete absence of collinearity between this predictor variable and other predictor variables including "Bank branches per 100,000 of adult populations", "ATMs PER 100,000 of adult populations" and "Debit accounts per 1000 of the population" (Daoud, 2018). Likewise, the VIF value for "Bank branches per 100,000 of adult populations", "ATMs per 100,000 of adult populations" and "Debit accounts per 1,000 population" are $8.437,8.595$ and 9.539 which are close to 10 as such they show a high level of collinearity (O’Brien, 2007) but acceptable.

The Durbin Watson test is used to check the autocorrelation between the variables in the multiple regressions model. The value for the test came as 1.879 which shows a small degree of positive autocorrelation. However, as it is close to 2 it is accepted as the rule of thumb says value between 1.5 and 2.5 is acceptable. The final equation of regression can be composed as follows:

$$
Y=20.359 X-653.339
$$

$\mathbf{Y}=$ "GDP per capita".

$\mathbf{X}=$ "Credit accounts per 1,000 of population".

While considering the above result, there is a significant relationship between "credit accounts per 1,000 of populations" and "GDP per capita." Further, it is checked on a more significant set of data from 1989 to 2017 given in Table 10

Table 10.

Data in the given table is taken from $\underline{\mathrm{RBI}}$ statistics and World Bank data

\begin{tabular}{|c|c|c|c|}
\hline Years & "GDP per capita" & $\begin{array}{c}\text { "Credit A/C per } \\
\mathbf{1 , 0 0 0} \text { populations" }\end{array}$ & $\begin{array}{c}\text { "Deposit A/C per } \\
\mathbf{1 , 0 0 0} \text { populations." }\end{array}$ \\
\hline $\mathbf{1 9 8 9}$ & 346.1128 & 60.9270 & 353.0816 \\
\hline $\mathbf{1 9 9 0}$ & 367.5566 & 61.6642 & 381.6815 \\
\hline
\end{tabular}

2020 | Annals of Management and Organization Research / Vol 1 No 3, 187-202 


\begin{tabular}{|c|c|c|c|}
\hline 1991 & 303.0556 & 69.5028 & 398.5208 \\
\hline 1992 & 316.9539 & 72.4287 & 406.6382 \\
\hline 1993 & 301.1590 & 66.9783 & 409.4343 \\
\hline 1994 & 346.1029 & 63.0825 & 419.7104 \\
\hline 1995 & 373.7664 & 60.2714 & 404.6331 \\
\hline 1996 & 399.9500 & 57.6903 & 399.0470 \\
\hline 1997 & 415.4937 & 55.5679 & 396.2223 \\
\hline 1998 & 413.2989 & 52.5609 & 392.3868 \\
\hline 1999 & 441.9987 & 50.3873 & 391.0262 \\
\hline 2000 & 443.3141 & 51.4596 & 390.7103 \\
\hline 2001 & 451.5730 & 48.7116 & 398.1664 \\
\hline 2002 & 470.9867 & 51.5760 & 402.4367 \\
\hline 2003 & 546.7266 & 53.5220 & 401.3231 \\
\hline 2004 & 627.7742 & 58.7717 & 404.6994 \\
\hline 2005 & 714.8610 & 67.2275 & 406.7514 \\
\hline 2006 & 806.7532 & 73.3050 & 416.2193 \\
\hline 2007 & 1028.3347 & 79.8184 & 438.8056 \\
\hline 2008 & 998.5223 & 89.1094 & 484.4437 \\
\hline 2009 & 1101.9608 & 90.3782 & 543.8849 \\
\hline 2010 & 1357.5637 & 96.1272 & 595.3821 \\
\hline 2011 & 1458.1035 & 96.5568 & 647.9543 \\
\hline 2012 & 1443.8795 & 103.3984 & 713.5505 \\
\hline 2013 & 1449.6059 & 100.158 & 815.9489 \\
\hline 2014 & 1573.8814 & 107.0928 & 946.8246 \\
\hline 2015 & 1605.6054 & 110.0940 & 1099.0263 \\
\hline 2016 & 1732.5642 & 122.5917 & 1242.8116 \\
\hline 2017 & 1981.6510 & 128.7736 & 1364.5388 \\
\hline
\end{tabular}

Table 11. Descriptive analysis

"Descriptive Statistics"

\begin{tabular}{|l|c|c|c|}
\hline & "Mean" & "Std. Deviation" & "N" \\
\hline "GDPPer Capita" & 821.348610 & 528.3850057 & 29 \\
"Number of credit accounts per1000 & 75.852869 & 23.4601968 & 29 \\
$\begin{array}{l}\text { population" } \\
\text { "Number of debit accounts per 1000 } \\
\text { populations." }\end{array}$ & 553.995176 & 276.7532906 & 29 \\
\hline
\end{tabular}

Table 12 shows the model summary of a more extensive data set after running multiple linear regressions by adopting the step-wise method.

Table 12. Model Summary ${ }^{b}$

\begin{tabular}{|l|c|c|c|c|c|}
\hline "Model" & "R" & "R Square" & $\begin{array}{c}\text { "Adjusted R } \\
\text { Square" }\end{array}$ & $\begin{array}{c}\text { "Std. Error of the } \\
\text { Estimate" }\end{array}$ & "Durbin-Watson" \\
\hline 1 & .944 a & .890 & .886 & 178.2380664 & .331 \\
\hline
\end{tabular}

a. Predictors: (Constant), "Number of credit accounts per 1,000 populations"

b. Dependent Variable: "GDPPer Capita"

The proposed model shows $94.40 \%$ of correlation between "GDP per capita" and "accounts credited per 1,000 of populations". Adjusted R square shows $88.60 \%$ of the variance in "GDP per capita" can be predicted by "account credited per 1,000 populations". The model shows a high positive correlation between the variable as "Durbin-Watson" value is . 331 . 
Table 13 represents the calculated $\boldsymbol{F}$ value (219.070), $\boldsymbol{P}$ value (.000) and Mean squares residual (31768.808).

Table 13 ANOVA ${ }^{\mathrm{a}}$

\begin{tabular}{|ll|c|c|c|c|c|}
\hline & "Model" & $\begin{array}{c}\text { "Sum of } \\
\text { Squares" }\end{array}$ & "df" & $\begin{array}{c}\text { "Mean } \\
\text { Square" }\end{array}$ & "F" & "Sig." \\
\hline \multirow{2}{*}{1} & Regression & 6959582.175 & 1 & 6959582.175 & 219.070 & $.000^{\mathrm{b}}$ \\
& Residual & 857757.824 & 27 & 31768.808 & & \\
& Total & 7817339.999 & 28 & & & \\
\hline
\end{tabular}

a. Dependent Variable:" GDP Per Capita"

Predictors: (Constant), "Number of credit accounts per 1,000 populations".

On dividing mean square regression by mean square residual, we get $\mathrm{F}$ value which is (219.070). Significant value is zero which is less than .05 so "account credited per 1000 of the population" can predict the "GDP per capita" hence the alternate hypothesis to H01b is true. Coefficients details are depicted in Table 14 VIF value 1 for credit account per 1,000 is 1, representing the absence of collinearity between the predictor variables.

Table 14. Coefficients ${ }^{\mathrm{a}}$

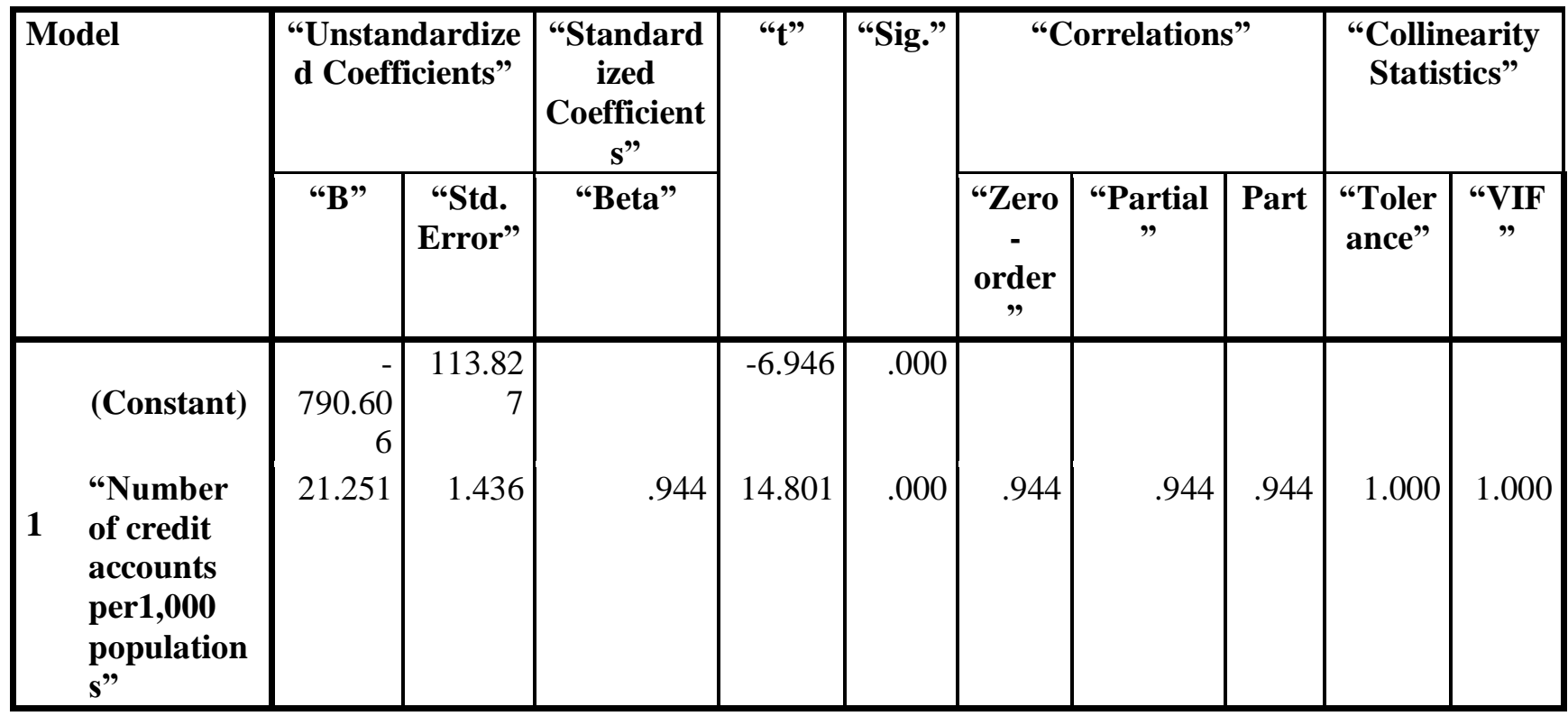

a. Dependent Variable: "GDP per capita"

Derived regression equation from the above-proposed model can be written as follows:

$B=21.251 A-790.606$

$\mathrm{B}=$ "GDP per capita".

$\mathrm{A}=$ "Credit accounts per 1,000 population".

Table 15. Excluded Variables ${ }^{\mathrm{a}}$

\begin{tabular}{|c|c|c|c|c|c|c|c|}
\hline \multirow[t]{2}{*}{ "Model" } & \multirow{2}{*}{$\begin{array}{l}\text { "Bet } \\
\text { a } \\
\text { In" }\end{array}$} & \multirow[t]{2}{*}{ "to" } & \multirow[t]{2}{*}{ "Sig." } & \multirow{2}{*}{$\begin{array}{c}\text { "Partial } \\
\text { Correlation" }\end{array}$} & \multicolumn{3}{|c|}{ "Collinearity Statistics" } \\
\hline & & & & & "Tolerance & "VIF & $\begin{array}{l}\text { "Minimum } \\
\text { Tolerance" }\end{array}$ \\
\hline $\begin{array}{ll} & \text { "Number of debit } \\
1 & \begin{array}{l}\text { accounts per } 1,000 \\
\text { populations." }\end{array}\end{array}$ & $.222^{\mathrm{b}}$ & 1.552 & 133 & 291 & .189 & 5.288 & .189 \\
\hline
\end{tabular}

a. Dependent Variable: "GDPPer Capita"

2020 | Annals of Management and Organization Research / Vol 1 No 3, 187-202 
b. Predictors in the Model: (Constant), "Number of credit accounts per 1,000 population"

Result found after analysis gives $\boldsymbol{P}$ value for "Deposit accounts per 1,000 of population" at .133 which is more than the acceptable value of .05 so "deposit accounts per 1,000 population" do not have a significant relation with "GDP per capita" and $t$ value of 1.552 being $<2$ which makes the proposed hypothesis H01a true.

\section{Results}

* According to the above study, only the "Credit accounts per one thousand populations" depicts a significant relationship with "GDP per capita". Change in one variable shows a change in another.

* "Bank branches per 100,000 of the adult population" and "ATMs per 100,000 of adult population" along with "Deposit accounts per 1,000 population" do not significantly affect the GDP per capita.

* The data used in the analysis is considered normal, linear and homogeneous as three diagrams depict the same.

\section{Conclusion}

Financial inclusion is an ongoing process in which banks play an essential role in mobilizing finance from the source to where it is needed and helps in the country's economic growth. There is a cause-andeffect relationship between the country's "GDP per capita" and the "F.I". For this above analysis is performed and literature review is done, there is a positive effect of change in "Credit accounts per 1,000 population" on the "GDP per capita". The number of "Bank branches per 100,000 of the adult population"; "ATMs per 100,000 of adult population" along with "Deposit accounts per 1,000 of the population" have no significant impact on the "GDP per capita". Paper proves that only "Credit accounts per 1,000 people" have a significant relationship with "GDP per capita". So, if the number of "credit accounts" increases or decreases, that will show some change in GDP per capita.

\section{Limitations and forward study}

* Data on "ATMs" and "Bank branches per 100,000 of the adult population" is not present for the era before 2004, decreasing the depth of analysis. If the same is provided, an in-depth study may be conducted to establish the relationship between the four indicators of "financial inclusion" and "GDP per capita of the country."

* State-wise data do not present a comparative study between the states. It cannot find where the maximum impact of "financial inclusion" on "GDP per capita" is located.

\section{References}

Ambarkhane, D., Singh, A. S., \& Venkataramani, B. (2016). Measuring financial inclusion of Indian States. International Journal of Rural Management, 12(1), 72-100. https://doi.org/10.1177/0973005216633940

Babajide, A. A., Adegboye, F. B., \& Omankhanlen, A. E. (2015). Financial inclusion and economic growth in Nigeria. International Journal of Economics and Financial Issues, 5(3), 629-637. https://doi.org/10.38157/business-perspective-review.v2i2.149

Bech, H., \& Kunt, A. D. (2012). Financial inclusion-an on going process.

Bhaskar, P. V. (2013). Financial inclusion in India - An Assessment 1. MFIN and Access-Assist Summit Organized in New Delhi, 1-23.

Central, B. I. S., \& Chakrabarty, K. C. (2011). Financial inclusion and banks - issues and perspectives. Financial Inclusion: Partnership between Banks, MFIs and Communities, 1-9.

Chakrabarty, K. C. (2012). Financial inclusion - issues in measurement and analysis. https://doi.org/10.1002/9780470978160.ch11

Chakravarty, S. R., \& Pal, R. (2013). Financial inclusion in India: an axiomatic approach. Journal of Policy Modeling, 35(5), 813-837. https://doi.org/10.1016/j.jpolmod.2012.12.007

Chibba, M. (2009). Financial inclusion, poverty reduction and the millennium development goals.
Europea
Journal of
of Development
Research,
21(2),
213-230.

https://doi.org/10.1057/ejdr.2008.17 
Conroy, J. (2006). APEC and financial exclusion: missed opportunities for collective action? AsiaPacific Development Journal, 12(1), 53-79. https://doi.org/10.18356/339ee7fc-en

Daoud, J. I. (2018). Multicollinearity and regression analysis. Journal of Physics: Conference Series, 949(1). https://doi.org/10.1088/1742-6596/949/1/012009

Dinabandhu Sethi, D. A. (2018). Financial inclusion and economic growth linkage: some cross country evidence. Journal of Financial Economic Policy, 10(3), 369-385. https://doi.org/10.1108/JFEP11-2016-0073

Evans, O., \& Alenoghena, R. (2017). Financial Inclusion and GDP Per Capita in Africa: A Bayesian VAR Model. Journal of Economics and Sustainable Development, 8(18), 44-57. Retrieved from www.iiste.org

Fund, I. M. (n.d.). Financial Access Survey: Glossary of Indicators and Concepts.

Gozgor, G., \& Gozgor, K. (2013). The relationship between domestic credit and income: Evidence from Latin America. Applied Econometrics and International Development, 13(1), 89-98.

Iqbal, B. A., \& Sami, S. (2017). Role of banks in financial inclusion in India. Contaduria y Administracion, 62(2), 644-656. https://doi.org/10.1016/j.cya.2017.01.007

Jayanthi, M., \& Rau, S. S. (2017). Financial inclusion in India. International Journal of Applied Business and Economic Research, 15(22), 11-16.

Joseph, J., \& Varghese, T. (2014). Role of financial inclusion in the development of Indian economy. Journal of Economics and Sustainable Development, 5(11), 2222-1700. Retrieved from www.iiste.org

Julie, O. (2013). The relationship between financial inclusion and GDP growth in Kenya. (University of Nairobi). Retrieved from http://erepository.uonbi.ac.ke/bitstream/handle/11295/58543/Oruo_Financial Inclusion and GDP Growth .pdf? sequence $=3$

Kablana, A. S. K., \& Chhikara, K. S. (2013). A Theoretical and quantitative analysis of financial inclusion and economic growth. Management and Labour Studie. https://doi.org/10.1177/0258042X13498009

Kapoor, A. (2014). Financial inclusion and the future of the Indian economy. Futures, 56, 35-42. https://doi.org/10.1016/j.futures.2013.10.007

Kim, D. W., Yu, J. S., \& Hassan, M. K. (2018). Financial inclusion and economic growth in OIC countries. Research in International Business and Finance, 43, 1-14. https://doi.org/10.1016/j.ribaf.2017.07.178

Kim, J. H. (2016). A study on the effect of financial inclusion on the relationship between income inequality and economic growth. Emerging Markets Finance and Trade, 52(2), 498-512. https://doi.org/10.1080/1540496X.2016.1110467

Kumar, C., \& Mishra, S. (2011). Banking outreach and household level access : analyzing financial inclusion in India. 13th Annual Conference on Money and Finance, (February 2011), 1-33.

Kumar, N. (2013). Financial inclusion and its determinants: evidence from India. Journal of Financial Economic Policy, 5(1), 4-19. https://doi.org/10.1108/17576381311317754

Lenka, S. K., \& Sharma, R. (2017). Does financial inclusion spur economic growth in India? The Journal of Developing Areas, 51(3), 215-228. https://doi.org/10.1353/jda.2017.0069

Leyshon, A., \& Thrift, N. (1995). Geographies of financial exclusion: financial abandonment in Britain and the United States. Transactions of the Institute of British Geographers, 20(3), 312. https://doi.org/10.2307/622654

Mandira Sarma, J. P. (2011). Financial inclusion and development: a cross country analysis. Journal of International Development, 6(1), 30. https://doi.org/10.14707/ajbr.160020

Mohan, R. (2006). Reserve bank of India bulletin economic growth, financial deepening and financial inclusion. In Reserve Bank of India Bulletin.

O'Brien, R. M. (2007). A caution regarding rules of thumb for variance inflation factors. Quality and Quantity, 41(5), 673-690. https://doi.org/10.1007/s11135-006-9018-6

Park, C.-Y., \& Mercado, R. J. (2015). Financial inclusion, poverty, and income inequality in developing Asia. SSRN Electronic Journal, (January 2015). https://doi.org/10.2139/ssrn.2558936

Rahman, M. S. (2013). Relationship among GDP , per capita GDP, literacy rate and unemployment rate. British Journal of Arts and Social Sciences NoII British Journal of Arts and Social Sciences, 
14(December 2011), 169-177. Retrieved from http://www.bjournal.co.uk/BJASS.aspx

RBI. (2008). Financial inclusion 7.1. RBI, p. 55. Retrieved from https://www.rbi.org.in/scripts/PublicationsView.aspx?id=10494

Reyes, G. P. (2010). Financial inclusion indicators for developing countries: the Peruvian case. In Cgap. Retrieved from https://www.afi-global.org/sites/default/files/fidwg_peruindicators_priale.pdf

Roa, M. J. (2014). Financial inclusion in Latin America and the Caribbean: access, usage and quality. Emerging Issues in Financial Development: Lessons from Latin America, (April), 91-127. https://doi.org/10.1596/978-0-8213-9828-9_ch2

Sahay, R., Cihak, M., N'Diaye, P., Barajas, A., \& Mitra, S. (2015). Financial inclusion: can it meet multiple macroeconomic goals? In Staff Discussion Notes (Vol. 15). https://doi.org/10.5089/9781513585154.006

Santiago Carbo, E. P. . G. and P. M. (2005). Financial exclusion. In Palgrave Macmillan. https://doi.org/10.1016/B978-008044910-4.00160-7

Sarma, M. (2008a). Index of financial inclusion (No. 215). Retrieved from http://hdl.handle.net/10419/176233\%0A

Sarma, M. (2008b). Index of Financial Inclusion (No. Working Paper, No. 215). New Delhi.

Sathye, M. (2003). Efficiency of banks in a developing economy: The case of India. European Journal of Operational Research, 148(3), 662-671. https://doi.org/10.1016/S0377-2217(02)00471-X

Sethi, D., \& Sethy, S. K. (2019). Financial inclusion matters for economic growth in India: Some evidence from cointegration analysis. International Journal of Social Economics, 46(1), 132 151. https://doi.org/10.1108/IJSE-10-2017-0444

Sharma, A., \& Sumita, K. (2013). An analytical study:relevance of financial inclusion for developing nations. Research Inventy: International Journal Of Engineering And Science, 2(6), 15-20. Retrieved from https://s3.amazonaws.com/academia.edu.documents/32945705/D033015020.pdf?AWSAccess KeyId=AKIAIWOWYYGZ2Y53UL3A\&Expires=1548237843\&Signature=VLR0WhhGvjIx 1 \%2FV1297sEk9E7S0\%3D\&response-content-disposition=inline\%3B filename\%3DAn_Analytical_Study_Relevance_of_Fi

Sharma, D. (2016). Nexus between financial inclusion and economic growth: evidence from the emerging Indian economy. Journal of Financial Economic Policy, 8(1), 13-36. https://doi.org/10.1108/JFEP-01-2015-0004

Srinivasan, N. (2007). Policy issues and role of banking system in financial inclusion. Economic and Political Weekly, 42(30), 3091-3095.

Swamy, V. (2010). Bank-based financial intermediation for financial inclusion and inclusive growth. Banks and Bank Systems, 5(4), 63-73. https://doi.org/10.2139/ssrn.2126834

The World Bank. Annual report 2018. World Bank Group.

Williams, H. T., Adegoke, A. J., \& Dare, A. (2017). Role of financial inclusion in economic growth and poverty reduction in a developing economy. Internal Journal of Research in Economics and Social Sciences (IJRESS), 22(1), 19-56. 